\title{
METHOD FOR RESERVOIR OIL RECOVERY IMPROVEMENT AT PLANNING THE FORMATION HYDRAULIC FRACTURING WITH USE OF A PACKER ASSEMBLY
}

. . сифов, . . няк, . • скеров, . . сифов

T. Yu. Yusifov, S. G. Panyak, A. A. Askerov, A. Yu. Yusifov

$$
\begin{aligned}
& \text { « - } \phi \text { нефть», } \quad \text { льский госуд рственный горный университет, } к \text { теринбург, } \\
& \text { « - урнефтег з», сифов . . « - ервис» }
\end{aligned}
$$

лючевые слов : гидрор зрыв пл ст ( ); с отсечением горизонт льного ствол; $\boldsymbol{n}$ керн $\boldsymbol{g}$ компоновк -168; рекольм т ция трещины; мостов я пробк; норм яиз ция з боя скв жины Key words: formation hydraulic fracturing $(\mathrm{FHF}) ; \mathrm{FHF}$ with isolating the horizontal hole;

packer assembly (PC-168C); fracture re-colmatage; bridge plug; well bottom-hole normalization

идр влический р зрыв пл ст имеет много технологических решений, которые обусловлены $р$ зличными особенностями к ждого конкретного объект обр ботки и конструкции скв жин.

зличные способы проведения требуют использов ния определенных видов п керной компоновки, отвеч ющих требов ниям технологических процессов, т кже скв жинных условий. очный выбор и применяемость любой технологии с учетом конкретных геологических условий и структуры скв жины обеспечив ет м ксим льную эффективность после опер ции [1].

обычной пр ктике техногенные ф кторы, сниж ющие нефтеотд чу, обусловлены ремонтными р бот ми после . ешение проблем ухудшения фильтр ционно-емкостных $\mathrm{x} \mathrm{p} \mathrm{ктеристик} \mathrm{(приз} \mathrm{бойной} \mathrm{зоны} \mathrm{пл} \mathrm{ст} \mathrm{)} \mathrm{после} \mathrm{промывочной} \mathrm{жидкостью} \mathrm{по} \mathrm{сей}$ день является кту льным [2].

сновн я 3 д ч 3 ключ ется в том, чтобы не кольм тиров ть нижние продуктивные пл сты скв жин р створом глушения и промывочной жидкостью после проведения т кже трещину проектного объект .

огл сно существующей ст нд ртной технологии р бот н скв жин х с горизонт льным уч стком необходимо изолиров ть горизонт льный хвостовик с использов нием мостовой пробки ( $\quad$ ) и провести в вертик льной ч сти эксплу т ционной колонны. осле 3 вершения гидрор зрыв проводится длительн я норм лиз ция з боя с р збурив нием песч ного мост . родолжительн я р бот с промывочной жидкостью приводит к рекольм т ции созд нной трещины и с сорению нижнего горизонт льного уч стк скв жины [3].

спользов ние п керной компоновки «роизводственн я фирм « кер улз»

-168 н месторождениях « - урнефтег з» способствов ло пр ктическому решению $з$ д ч.

керн я компоновк -168 состоит из двух п керов (верхнего гидр влического и нижнего мех нического), которые огр ничив ют интерв л перфор ции. ежду п кер ми уст н влив ется перфориров нн я (н сосно-компрессорн я труб) ди метром 89 мм, через которую 3 к чив ется ре гент в пл ст (рис.1). к чк предусм трив ет р боту при д влении до 60 м [4].

ущность д нного метод з ключ ется в том, что пр ктически исключ ется дополнительн я норм лиз ция з боя скв жины после гидрор зрыв . оризонт льный уч сток скв жины отсек ется п керной компоновкой, гидрор зрыв проводится н вертик льной ч сти скв жины (н вышележ щем пл сте), з тем производится срыв верхнего п кер , через промывочный узел вымыв ются ост тки продуктов р зрыв , и проводится глушение скв жины. осле подъем компоновки п кер спуск ется (глубинно-н сосное оборудов ние) без норм лиз ции з боя скв жины.

ыл проведен опытно-производственн я р бот н скв. 3103 р совского месторождения. кв жин имеет горизонт льный уч сток ствол, гидрор зрыв был произведен в вертик льной ч сти скв жины с временным отсечением горизонт .

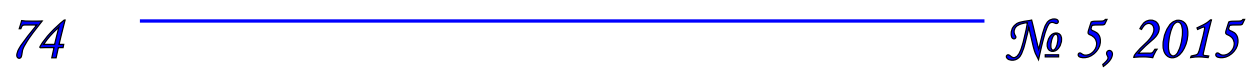




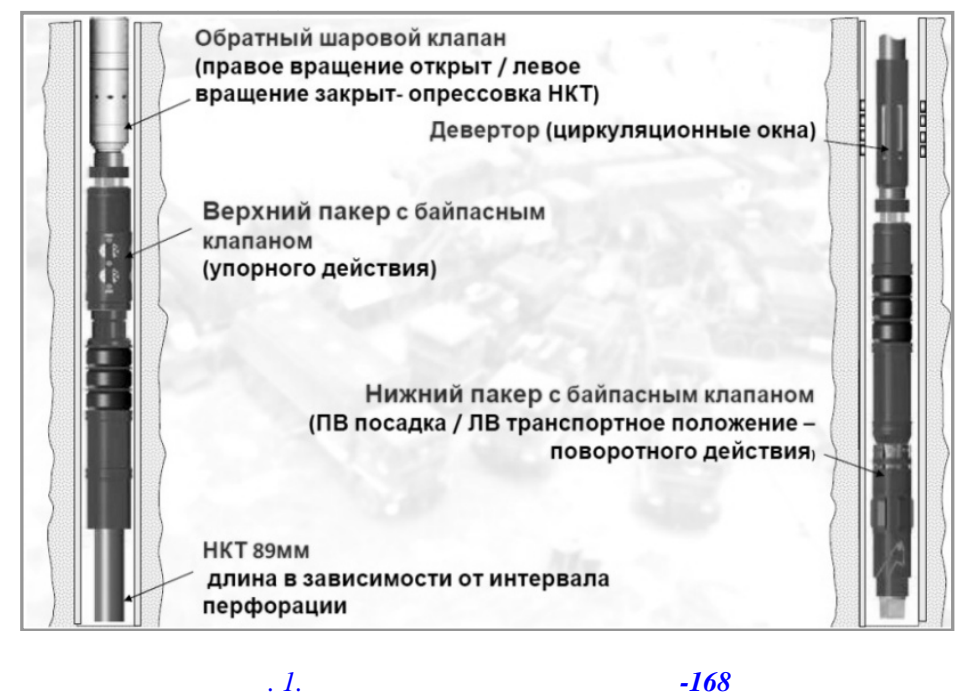

внедрением технологии « « кер улз» отп л необходимость норм лиз ции з боя, тем с мым были сокр щены сроки ввод скв жины в эксплу т цию после рис. 2 приведены п р метры эксплу т ции скв. 3103 р совского месторождения до и после . ок з но, что дебит нефти вырос н 10 тонн в сутки.

ис. 2. ебит жидкости, нефти до и после по скв. 3103 р совского $\mathrm{M} / \mathrm{p}$

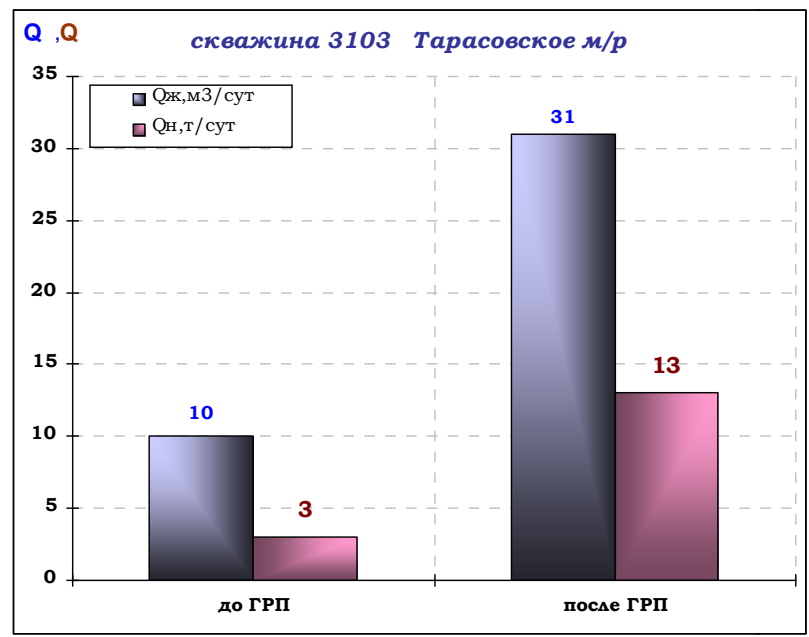

осле получения положительных результ тов было принято решение производить н логичную технологию и н других скв жин х, где р нее не проводился гидрор зрыв в связи с тем, что эти скв жины имеют горизонт льный уч сток, д ющий нефть, но с низким пл стовым д влением [5]. $\quad$ н вертик льной ч сти мог приводить к потере нефтеотд чи скв жин с горизонт льного уч стк из-з 3 сорения промывочной жидкостью при норм лиз ции 3 боя.

рис. 3 приведены результ ты ре лиз ции опер ции по скв. 7172 омсомольского месторождения. 3 предст вленных д нных видно, что дебит по нефти вырос н 6 т/сут.

ледует отметить, что основной $з$ д чей при внедрении технологии было предотвр щение потери нефтеотд чи пл стов. тличительн я комплексн я особенность д нного метод состоит в том, что исключ ется необходимость отсыпки песком нижнего горизонт льного уч стк скв жины, не кольм тируются продуктивные пл сты, т к к к отп д ет норм лиз ция з боя после проведения гидрор зрыв , зн чительно сокр щ ется продолжительность и стоимость ремонт скв жин.

счет экономического эффект от использов ния д нных компоновок при гидрор зрыве с изоляцией дополнительного хвостовик по одной опер ции ф ктически сост вляет 250-345 бр./ч с. двух скв жин х 3103/152 и 7172/102 время введения их в р боту ф к- 
тически сокр тилось н $58 \%$, сумм рный экономический эффект сост вил 595 бр./ч с, в среднем - 297,5 бр./ч с, в денежном эквив ленте -1,8 млн руб. н к ждую опер цию.

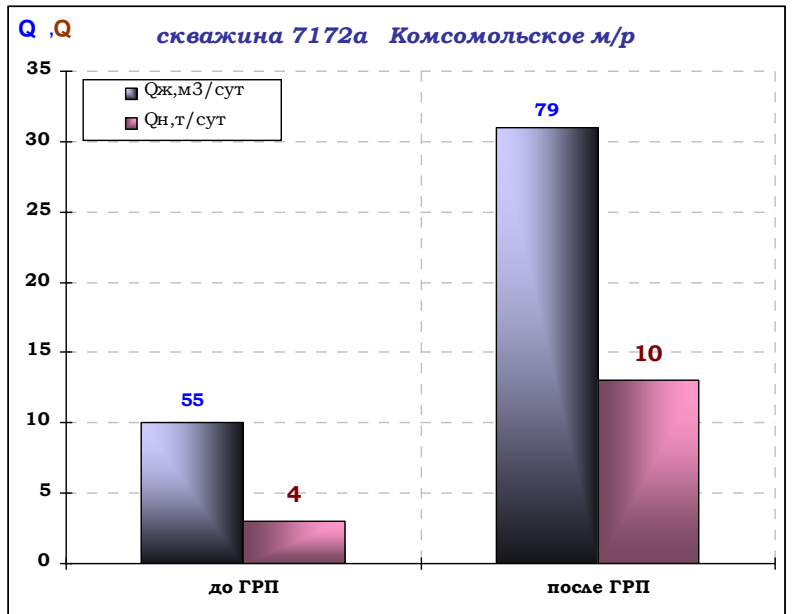

ис. 3. ебит жидкости,

нефти до и после

по скв. 7172

омсомольского м/p

внедрением д нной технологии открылись перспективы для проведения жин х с временным отсечением горизонт льного ствол, и еще н 14 скв жин х пл нируются н логичные опер ции. л нируемый сумм рный экономический эффект в среднем может сост вить 3867,5 бр./ч с, в денежном эквив ленте - в среднем 23,4 млн руб. н проектные скв жины.

blводы

- $\quad$ сключ ется необходимость отсыпки песком (пропп нтом) нижнего горизонт льного уч стк скв жины.

- тп д ет необходимость норм лиз ции з боя скв жины после опер ции, , соответственно не з соряется нижний эксплу т ционный интерв л р створом, т кже проектный пл ст.

- $\quad$ водятся в р боту без потери дебит жидкости и нефти пл сты, которые не подверглись гидрор зрыву.

- $\quad$ н чительно сокр щ ется продолжительность ремонт скв жин, н которых проводятся гидрор зрывы, сниж ются з тр ты н ремонт.

писок литер туры

1. ж. ич, осковидис ересмотр современных успехов в технологии гидрор зрыв : м т-лы конференции инженеров-нефтяников. - 1986.

2. Economides M. J. Reservoir stimulation / Economides M. J., Nolte K. G. // Prentice Hall. Eglewood Cliffs, - New Jersey 07632. - 1989. - . 430.

3. Hannah P. R. Fracturing a high permeability oil well at Prudhoe Bay, Alaska / Hannah P. R., Walker E. J. // Paper SPE $14372 .-1985 .-13$

4. н лиз внедрения п керной компоновки, используемой при н месторождениях « - урнефте Г $3 \gg-2014$ г.

5. сифов . идрор зрыв нефтяных пл стов с низким д влением (н примере месторождений урнефтег з») / . . сифов // ефтег зовое дело. - 2012. - № 3. - . 179-184.

\footnotetext{
ведения об вторе

сифов еюб сифоглы, к. т. н., гл вный спе ци лист "оснефть - фимский н учно исследов тельский и проектный институт», г. $\phi$, тел.89373087202,e-mail: YusifovTY@ufanipi.ru

няк теф н ригорьевич, д. г.-м. н., $з$ ведующий к федрой геологии и , венный горный университет, г. $к$ теринбург, тел 8(343)2574105, e-mail: panjaks@rambler.ru

скеров мил киф оглы, спир нт, р льский госуд рственный горный университет, 2. к теринбург,тел.8(34936)57539,e-mail: Askerov.A.M@mail.ru сифов лы сиф оглы, н ч льник трубного уч сткк " mail: YusifovTY@ufanipi.ru
}

Information about the author

Yusifov T. Yu., Candidate of Science in Engineering, chief specialist of LLC «Rosneft - Ufa Research and Designing Institute», Ufa, phone: 89373087202, e-mail: YusifovTY@ufanipi.ru

Panyak S. G., Doctor of Geology and Mineralogy, head of the chair of geology, the Ural State Mining University, phone: 8(343)2574105,e-mail: panjaks@rambler.ru

Askerov A. A., postgraduate, the Ural State Mining University, phone: 8(34936)57539, e-mail: Askerov.A.M@mail.ru

Yusifiv A. Yu., chief of the pipe yard in CPP $L C$ «PNGKRS», phone: 89220544232,e-mail: YusifovTY@ ufanipi.ru 